\title{
Bio Efficacy of Fungicides and Bio Agents against Ceratocystis fimbriata Ell. and Halst. Causing Wilt Disease of Pomegranate
}

\author{
H.S. Imran Khan ${ }^{1 *}$, H. Ravindra ${ }^{1}$, Suresh Ekbote ${ }^{1}$, H. Narayaswamy ${ }^{1}$, \\ P. Narayanaswamy ${ }^{1}$ and S. Pradeep ${ }^{2}$
}

\author{
${ }^{1}$ Department of Plant pathology, University of Agricultural and Horticultural Sciences (UAHS), \\ Navile, Shivamogga, Karnataka, India \\ ${ }^{2}$ Organic Farming Research Centre, UAHS, Shivamogga, India \\ *Corresponding author
}

\section{A B S T R A C T}

Pomegranate wilt disease incited by Ceratocystis fimbriata Ell. And Halst.

Keywords

Ceratocystis

fimbriata, Soil

borne, Fungicides,

Bioagents,

Inhibition.

Article Info

Accepted:

26 May 2017

Available Online:

10 June 2017

Is one of the important diseases of pomegranate adversely affecting crop cultivation in all major growing regions of Karnataka. The pathogen being soil borne preventive measures are of prime importance to manage this disease. Hence present in vitro studies were undertaken. The results obtained on fungicides evaluation revealed among the different systemic fungicides tested, cent per cent inhibition of mycelial growth of $C$. fimbriata was recorded in propiconazole followed by hexaconazole 94.65 per cent, respectively followed by non-systemic fungicides Thiram (74.35 $\%$ ) followed by copper oxy chloride $(70.52 \%)$. Among the different bio agents tested against $C$. fimbriata, $T$. harzianum was found to be the most effective with the highest inhibition of mycelial growth $(88.77 \%)$ followed by $T$. viride $(86.60 \%)$ and P. fluorescens $(66.33 \%)$. Bacillus subtilis was found less effective with $(54.88 \%)$ inhibition.

\section{Introduction}

Pomegranate (Punica granatum L) is one of the important fruit crops grown in tropics, subtropics regions of the world showing its versatile adaptability to a wide range of climatic conditions. Area under pomegranate is increasing worldwide because of its hardy nature, wider adaptability, and drought tolerance, higher yield levels with excellent keeping quality and remunerative prices in domestic as well as export market. It is commercially cultivated in states of Maharashtra, Karnataka, Andhra Pradesh, Gujarat, Rajasthan and Tamil Nadu. Among the different states growing pomegranate, Maharashtra is the largest producer occupying two thirds of total area in the country followed by Karnataka, Andhra Pradesh, Gujarat and Rajasthan. In India, it is regarded as a vital cash crop grown in an area of 1, 43, 000 ha with a production of 1.77 MT with an 
average productivity of $12.39 \mathrm{t} / \mathrm{ha}$ (Anon. 2015). In Karnataka pomegranate is grown in an area of 19,000 ha with a production of 2,04,000 tonnes (http://www.horticulture. kar.nic.in), where this crop has spread across different districts viz., Vijayapura, Ballari, Bagalkot, Koppal, Chitradurga, Chickmagalur, Tumakuru, Bengaluru and Kalaburgi. However, during recent past, the pomegranate productivity seems to be declining, for which various biotic and abiotic factors are responsible (Sharma et al., 2008). Among the various biotic factors, the pomegranate wilt disease incited by Ceratocystis fimbriata Ell. and Halst. is one of the important diseases of pomegranate adversely affecting crop cultivation in all major growing regions of India (Somasekhara, 1999).

The disease is characterised by the initial symptoms like yellowing and wilting of leaves, wilting of one to several branches leading to death of affected plants in a few weeks. Cross sections of diseased stem revealed brown discoloration in the outer xylem from roots to the main trunk (Somasekhara and Wali, 2000).

It is very difficult to manage the pathogen with chemicals alone which seems to be ineffective and uneconomical. Therefore, present studies were undertaken to know the efficacy of fungicides and bio efficacy of bio agents against Ceratocystis fimbriata causing wilt of pomegranate.

\section{Materials and Methods}

\section{In vitro efficacy of fungicides}

The efficacy of four non-systemic and five systemic fungicides were tested against $C$. fimbriata for radial growth inhibition on the Potato Dextrose Agar (PDA) media using poisoned food technique (Nene and Thapliyal
1993) under in vitro condition. The nonsystemic fungicides were tested at 1000, 2000 and $3000 \mathrm{ppm}$ concentrations (Table 1), whereas, systemic fungicides were tested at 500 ppm, 1000 ppm and 2000 ppm concentrations respectively (Table 2 ).

\section{Poisoned food technique}

The poisoned food technique described by (Shravelle, 1961) was followed to evaluate the efficacy of systemic and non-systemic fungicides in inhibiting the mycelial growth of $C$. fimbriata. The test fungus was grown on PDA medium for 15 days prior to conducting the experiment. The PDA medium was prepared and melted. The fungicidal suspension was added to the melted PDA medium to obtain the required concentration on commercial formulation basis of the fungicide.

Twenty $\mathrm{ml}$ of poisoned medium was poured in each sterilized Petri plates. Check was maintained without addition of fungicide. Mycelial discs of $5 \mathrm{~mm}$ was taken from the periphery of 15 days old colony and was placed at the center of Petri plates and incubated at $25 \pm 1^{\circ} \mathrm{C}$ for 12 days and replicated thrice.

The diameter of the colony was measured in two directions and average was recorded. Per cent inhibition of mycelial growth of the fungus was calculated by using the formula described by Vincent (1947).

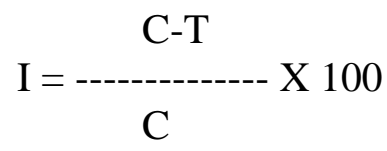

Where,

I - Per cent inhibition

C - Radial growth in control

$\mathrm{T}$ - Radial growth in treatment 


\section{In vitro efficacy of bioagents}

The efficacy of two fungal and two bacterial antagonists (Table 3) were evaluated in vitro against $C$. fimbriata applying dual culture technique (Dennis and Webster 1971). Ten days old cultures of the test bioagents, and the test pathogen $C$. fimbriata were used for the study. The culture discs (5 mm dia.) of the test pathogen and bioagents cut out with sterilized cork borer were aseptically inoculated, one each at equidistance and exactly opposite with each other on solidified PDA medium in Petri plates and incubated at $28 \pm 2^{\circ} \mathrm{C}$. Three replication were maintained and the experiment was designed with complete randomized design. PDA plates inoculated only with culture disc of the test pathogen were maintained as untreated control. Observations on linear mycelial growth of the test pathogen and bioagents were recorded at an interval of 24 hours, continued till untreated control plates were fully covered with mycelial growth of the test pathogen and finally computed the average colony growth. Per cent inhibition of mycelial growth of the fungus was calculated by using the formula given by Vincent (1947).

\section{Results and Discussion}

\section{In vitro efficacy of fungicides}

Results indicated that all of the four non systemic and six systemic fungicides tested at both the concentrations significantly inhibited mycelial growth of $C$. fimbriata, over untreated control and it was inversely proportional to the concentration of the test fungicides (Table 1 and 2).

\section{Mycelial growth inhibition}

Experimental results revealed that per cent mycelial growth inhibition with non-systemic fungicides tested ranged from 27.50 to 65.00 per cent at $1000 \mathrm{ppm}, 35.25$ to 74.35 per cent at $2000 \mathrm{ppm}$ and 46.25 to 86.15 per cent at 3000 ppm respectively (Table 1). However, significantly highest mycelial growth inhibition was recorded with Thiram (86.15 $\%)$ followed by Copper oxy chloride ( 84.25 $\%)$ and Mancozeb (71.65 \%). It was comparatively minimum with Captan (46.25 $\%)$. Thus, all the non-systemic fungicides tested were found effective against inhibition of the mycelial growth of $C$. fimbriata, over the control. However, per cent mycelial growth inhibition with systemic fungicides ranged from 35.55 to 72.77 per cent at 500 ppm, 48.70 to 94.44 per cent at $1000 \mathrm{ppm}$ and 71.50 to 1000 per cent at $2000 \mathrm{ppm}$ respectively (Table 2). Significant highest mycelial growth inhibition was recorded with Propiconazole (100.00 \%), followed by Hexaconazole $(94.65 \%)$ and Difenconazole $(85.70 \%)$. However, among these fungicides tested, the most effective in the order of merit were Propiconazole, Hexaconazole, Difenconazole, Metalaxyl, Thiram and Copper oxy chloride.

The present findings are in conformity with the results of Somasekhara (2009) who reported that the fungal growth and survival of $C$. fimbriata on PDA medium was completely inhibited by Carbendazim, Benomyl, Mancozeb, Ridomil, Ziram and Propiconazole. Kuldeep et al., (2011) reported in vitro efficacy of fungicides against wilt pathogen of pomegranate and found the complete inhibition of mycelial growth of $C$. fimbriata in carbendazim $(0.1 \%)$, Propiconazole $(0.2 \%)$, Hexaconazole $(0.1$ $\%)$, Mancozeb (0.2\%) and Captan (0.2\%). Ramanujam et al., (2005) reported the fungicides Carbendazim, Propiconazole and Hexaconazole (each @ 500 ppm) as highest inhibitory to Ceratocystis paradoxa. The fungicides viz Carbendazim, Propiconazole (each @ 500 ppm and 1000 ppm), Hexaconazole (@1000 ppm), Thiram and Captan (each@1000 ppm and 2000 ppm) were reported to cause complete inhibition of 
Table.1 Efficacy of non-systemic fungicides against $C$. fimbriata

\begin{tabular}{|c|l|c|c|c|}
\hline \multirow{2}{*}{$\begin{array}{l}\text { Sl. } \\
\text { No. }\end{array}$} & \multicolumn{1}{|c|}{ Treatments } & \multicolumn{3}{|c|}{ Inhibition (\%) } \\
\cline { 3 - 5 } & & $\mathbf{1 0 0 0} \mathbf{~ p p m}$ & $\mathbf{2 0 0 0} \mathbf{~ p p m}$ & $\mathbf{3 0 0 0} \mathbf{~ p p m}$ \\
\hline 1 & $\begin{array}{l}\text { Copper oxy chloride (Blitox } \\
50 \% \text { WP) }\end{array}$ & $65.00(54.57)$ & $70.52(56.85)$ & $84.25(67.11)^{*}$ \\
\hline 2 & Captan (Captaf 50\% WP) & $27.50(30.35)$ & $35.25(36.96)$ & $46.25(43.25)$ \\
\hline 3 & Thiram (Thiride 75\% WP) & $63.61(53.25)$ & $74.35(58.97)$ & $86.15(68.15)$ \\
\hline 4 & Mancozeb (Dithane M-45) & $44.44(40.67)$ & $48.00(44.12)$ & $71.65(57.85)$ \\
\hline 5 & Control & 0.00 & 0.00 & 0.00 \\
\hline & & S.Em \pm & \multicolumn{2}{|c|}{ C.D at 1\% } \\
\hline & Fungicides (F) & 0.69 & \multicolumn{2}{|c|}{2.21} \\
\hline & Concentration (C) & 0.46 & \multicolumn{2}{|c|}{1.63} \\
\hline & FXC & 0.32 & \multicolumn{3}{|c|}{} \\
\hline
\end{tabular}

*Figures in parenthesis are arcsine transformed values

Table.2 Efficacy of systemic fungicides against $C$. fimbriata

\begin{tabular}{|c|l|c|c|c|}
\hline \multirow{2}{*}{$\begin{array}{l}\text { Sl. } \\
\text { No. }\end{array}$} & \multicolumn{2}{|c|}{ Treatments } & \multicolumn{3}{|c|}{ Inhibition (\%) } \\
\cline { 3 - 5 } & & $\mathbf{5 0 0} \mathbf{~ p p m}$ & $\mathbf{1 0 0 0} \mathbf{~ p p m}$ & $\mathbf{2 0 0 0} \mathbf{~ p p m}$ \\
\hline 1 & Hexaconazole (Contaf 5 \% EC) & $66.66(51.26)$ & $88.00(63.00)$ & $94.65(70.85)^{*}$ \\
\hline 2 & Propiconazole (Tilt 25 \% EC) & $72.77(46.12)$ & $94.44(70.79)$ & $100.00(90.00)$ \\
\hline 3 & Difenconazole (Score 25 \% EC) & $62.50(51.33)$ & $70.15(60.23)$ & $85.70(67.85)$ \\
\hline 4 & Carbendazim 50\%WP (Bavistin) & $35.55(37.41)$ & $48.70(44.15)$ & $71.50(45.86)$ \\
\hline 5 & Metalaxyl (Ridomil 75 WP) & $56.38(45.17)$ & $68.33(54.40)$ & $72.22(63.32)$ \\
\hline 6 & Control & 0.00 & 0.00 & 0.00 \\
\hline & & S.Em \pm & \multicolumn{2}{c|}{ C.D at 1\% } \\
\hline & Fungicides (F) & 0.69 & \multicolumn{2}{c|}{2.16} \\
\hline & Concentration (C) & 0.45 & \multicolumn{2}{c|}{1.29} \\
\hline & FXC & 0.32 & \multicolumn{2}{c|}{1.10} \\
\hline
\end{tabular}

*Figures in parenthesis are arcsine transformed values

Table.3 Per cent inhibition of growth of $C$. fimbriata by different bioagents

\begin{tabular}{|l|c|c|}
\hline \multicolumn{1}{|c|}{ Bioagents } & Average colony diameter (mm) & Inhibition (\%) \\
\hline T. harzianum & 10.10 & $88.77(70.32)^{*}$ \\
\hline T. viride & 12.00 & $86.60(68.52)$ \\
\hline P. fluorescens & 30.30 & $66.33(54.63)$ \\
\hline B. subtilis & 40.60 & $54.88(47.68)$ \\
\hline Control & 90.00 & $0.00(0.00)$ \\
\hline \multicolumn{1}{|c|}{ S.Em \pm} & 0.41 & 0.86 \\
\hline C.D at 1\% & 1.12 & 2.12 \\
\hline
\end{tabular}

*Figures in parenthesis are arc sine transformed values 
Ceratocystis paradoxa, causing sett rot of sugarcane (Vijaya et al., 2007).

\section{In vitro efficacy of bioagents}

Results revealed that all the bioagents tested exhibited antagonistic activity against $C$. fimbriata and significantly inhibited its growth over untreated control (Table 3). Amongst the bioagents tested, T. harzianum was found to be most effective with least mycelial growth $(10.10 \mathrm{~mm})$ and its highest inhibition $(88.77 \%)$ of the test pathogen, followed by $\mathrm{T}$. viride with mycelial growth $(12.00 \mathrm{~mm})$ and inhibition of $(86.60 \%)$ and P. fluorescens $(66.33 \%)$. The antagonist B. subtilis was found least effective with 54.88 per cent inhibition. Results of the present study on antagonistic effects against $C$. fimbriata are in conformity with those reported earlier by several workers (Yadahalli, 2008).

Vijaya et al., (2007) who reported the bio agents Trichoderma species as highest inhibitory to $C$. fimbriata. The bio agents Trichoderma species viz., T. longibrachiatum, T. koningii, T. hamatum, T. harzianum and one bacterial antagonist P. fluorescens were reported to cause complete inhibition of Ceratocystis paradoxa, causing sett rot of sugarcane (Yadahalli, 2008). Joshi (1999) reported that $\mathrm{T}$. viride was found significantly superior which inhibited 73.50 per cent of mycelial growth of $C$. paradoxa. The mechanism involved in inhibition of the test fungus may be attributed to the release of antibiotic produced by T. viride (Dennis and Webster, 1971). Another possibility for reduction in mycelial growth of test fungus may be competition between test fungus and T. viride for nutrition and other growth factors. It was due to the penetration of the antagonistic hyphae into hyphae of the pathogen at the place of contact as confirmed by Mukherji et al., (2000).

\section{References}

ANONYMOUS, 2015, Horticulture statistics at a glance, DAC and FW pp.216, New Delhi.

DENNIS, C. AND WEBSTER, J., 1971, Antagonistic properties of species group of Trichoderma; Production of nonvolatile antibiotics. Transact. British Mycol. Soc., 57: 25-39.

JOSHI, S. N., 1999, Integrated management of sett-borne disease of sugarcane in northern Karnataka. M. Sc. (Agril) Thesis, Univ. Agril. Sci., Dharwad

KULDEEP, K. S., SHARMA, J. AND JADHAV, V. T., 2011, Etiology of Pomegranate Wilt and its Management. Fruit, Vegetable and Cereal Sci. and Biotech. 4:96-101.

MUKHERJI, S., TRIPATHI, H. S. AND RATHI, Y. P. S., 2000, Integrated management of wilt complex in French bean (Phaseolus vulgaris L.), J. Mycol. Pl. Pathol., 31: 213-215.

NENE, Y. L. AND THAPLIYAL, P. N., 1982, Fungicides in Plant Disease Control. Oxford and IBH Publishing House, New Delhi, p.163

RAMANUJAM, B., NAMBIAR, K. K. N. AND ROHINI, I., 2005, Effect of systemic fungicides, aqueous extracts of oil cakes and inorganic soil amendments on Thielaviopsis paradoxa and its antagonistic fungi in vitro. $J$. Plantation Crops. 33 (2):107-111 (Sharma et al., 2008).

SOMASEKHARA, Y. M. AND WALI., S.Y., 1999, New record of Ceratocystis fimbriata causing wilt of pomegranate. Pl. Dis., 83 (4): 400.

SOMASEKHARA, Y. M., AND WALI, 2000, Ceratocystis fimbriata: A threatening pathogen of pomegranate (Punica granatum L.) in Northern Karnataka. Res. Crops, 1(1): 63-66. 
SOMASEKHARA, Y. M., 2009, in vitro and in vivo evaluation of fungicides for the management of pomegranate wilt pathogen (Ceratocystis fimbriata). Paper Presented In: 2nd Inter. Symp. Pomegranate and minor including Mediterranean Fruits, Univ. Agric. Sci., Dharwad, June 23-27, pp.140-141

SHRAVELLE, V. G., 1961, the nature and use of modern fungicides. Burges Publication Company, Minneosota, USA, 308p.
VIJAYA, H. K. SRIKANT, K. AND YASHODA R. H., 2007, Evaluation of plant extracts against Ceratocystis paradoxa causing sett rot of sugarcane. Karnataka J. Agric. Sci., 20 (1): 168169.

VINCENT, J. M., 1947, Distribution of fungal hyphae in the presence of certain inhibitors. Nature, 159: 850.

YADAHALLI, K. B., 2008, Influence of organic amendments on sugarcane set rot development, International Journal of Plant Sciences,.3 (2): 556-557.

\section{How to cite this article:}

Imran Khan, H.S., H. Ravindra, Suresh Ekbote, H. Narayaswamy, P. Narayanaswamy and Pradeep, S. 2017. Bio Efficacy of Fungicides and Bio Agents against Ceratocystis fimbriata Ell. and Halst. Causing Wilt Disease of Pomegranate. Int.J.Curr.Microbiol.App.Sci. 6(6): 29022907. doi: https://doi.org/10.20546/ijcmas.2017.606.343 